\title{
RESIN MODIFIED GLASS IONOMER CEMENT SEBAGAI MATERIAL ALTERNATIF RESTORASI UNTUK GIGI SULUNG
}

\author{
Diana Setya Ningsih*
}

Keywords:

Resin modified glass

ionomer, primary

teeth, caries, fluoride

\section{ABSTRACT}

Glass ionomer cement $(\mathrm{GIC})$ is a material that can release fluoride to prevent caries especially in primary teeth. One of the developments of glass ionomer cement in the world of pediatry dentistry is resin-modified glass ionomer cement (RMGIC). The resin-modified glass ionomer cement were still maintaining the clinical advantages oforiginal material, such as fluoride realease, good compatibility and aestehetically. The mechanical properties of rmgic is more higher than gic. These materials have a better adhesion, higher moisture resistance, and a longer shelft life. This paper review aims to know the ability RMGIC as alternative restorative material for primary teeth.

\section{PENDAHULUAN}

Resin modified glass ionomer cement merupakan material restorasi yang dihasilkan dari penggabungan sifat semen ionomer kaca konvensional dengan resin komposit. Sifat yang dimiliki oleh resin modified glass ionomer cement lebih mendekati sifat semen ionomer kaca konvensional dibandingankan resin komposit. ${ }^{1,2,3}$ Perpaduan sifat ini, menyebabkan reaksi pengerasan pada resin modified glass ionomer cement terjadi dalam 2 tahapan yaitu reaksi asam basa dan polimerisasi. Reaksi asam basa terjadi pada saat pencampuran fluroaluminosilicate kaca dengan cairan asam (polialkenoat). Reaksi polimerisasi dengan aktifator kimia/sinar dilakukan pada hibrid ionomer untuk megaktifasikan monomer resin 2-hydoxyethylmethacrylate (HEMA) yang terdapat di dalam bubuk dan atau cairan hibrid ionomer. ${ }^{1,2,3}$

Kombinasi ini menyebabkan resin modified glass ionomer cement tetap mampu melepaskan ion fluor. Dari beberapa penelitian menunjukkan jumlah ion fluor yang dilepaskan oleh hibrid ionomer lebih banyak dibandingkan material restorasi lainnya seperti: resin komposit dan kompomer., 4,5,6,7 Namun. jumlah ion fluor yang dilepaskan oleh hibrid ionomer sedikit lebih rendah atau sama dengan jumlah ion fluor yang dilepaskan oleh semen ionomer kaca konvensional. ${ }^{8,9}$ Penelitian Ngo mencoba mengamati tingkat penetrasi fluor dan Stronsium ke daerah yang terdemineralisasi. ${ }^{10} \quad$ Kemampuan pelepasan ion fluor ini dipercaya mampu mencegah perkembangan karies sehingga dapat digunakan untuk gigi sulung.

Gigi sulung merupakan gigi yang paling mudah terserang karies. Hal ini disebabkan oleh morfologi gigi anak yang memiliki ketebalan email yang sangat tipis dibandingkan gigi permanen dewasa. ${ }^{11}$ Proses karies ini juga diperparah akibat kebiasaan anakanak dalam mengkonsumsi makanan/ minuman manis dan lengket sehingga proses demineralisasi berlangsung lebih lama dibandingkan remineralisasi. ${ }^{12}$

\section{TINJAUAN PUSTAKA}

\section{Komposisi Resin Modified Glass Ionomer}

\footnotetext{
*Departement Dental Material Fakultas Kedokteran Gigi Universitas Syiah Kuala
}

Korespondesi: dee_aceh@yahoo.co.id 
Komposisi resin modified glass ionomer hampir sama dengan komposisi semen ionomer kaca. Kandungan fluoroluminosilicate glass juga dijumpai pada bubuk resin modified glass ionomer cement. Perbedaan komposisi dijumpai pada liquid (cairan) dimana terdapat penambahan HEMA (2-hydoxyethylmethacrylate) selain mengandung asam polikarboksilat dan air. 13,14 Penambahan HEMA bertujuan sebagai wetting agent untuk mengurangi kerentanan ionomer cement terhadap air sehingga meningkatkan adhesi dan sifat mekanik RMGIC. Hal ini sesuai dengan penelitian Dong Xie dkk yang menyatakan HEMA dapat mempengaruhi sifat mekanik dari semen. Tujuan dari modifikasi dari semen ionomer kaca ini adalah untuk mengurangi atau meminimalisir sifat semen yang kurang estetis dan terlalu rapuh (brittle). ${ }^{15}$

\section{Reaksi Pengerasan}

Reaksi pengerasan resin modified glass ionomer cement pada umumnya terjadi hampir sama dengan reaksi pengerasan semen ionomer kaca konvensional. Reaksi pengerasan ini mengalami reaksi asam basa yang terjadi pada saat fluroaminosilicate glass dan asam polikarboksilat disatukan sehingga partikel kaca pecah dan terjadi pelepasan ion yang terbentuk (Al3+dan $\mathrm{Ca} 2+$ ). Perpindahan ion metal ke dalam fase liquid dari semen yang disebut dengan fase migrasi. Fase berikutnya adalah fase gelatin, pada fase ini terbentuk suatu gelatin oleh karena ion metal memicu terjadinya pengerasan sehingga rantai asam poliakrilat akan berikatan silang dengan kalsium. ${ }^{13,16}$

Pada saat yang sama, reaksi polimerisasi terjadi pada HEMA dan crossliking agent yang diawali dengan reaksi oksidasi dan reduksi atau katalis fotopolimerisasi. Reaksi ini akan membentuk satu campuran keras yang terjadi akibat terbentuknya ikatan hidrogen antara polimer HEMA dan asam polikarboksilat. Asam dengan ikatan ganda yang mampu berpolimerisasi akan mengikat produk lain yang akan membentuk monomer baru. Ikatan ganda dari monomer yang berpolimerisasi akan menghilang setelah pengerasan dan sejumlah kelompok karboksil pada asam poli akrilik menurun. Hal ini merupakan akibat lanjutan dari reaksi asam basa. ${ }^{13,16}$

Setelah pengerasan terjadi ketika ion metal yang mengelilingi rantai polyacid meningkat sehingga semen lebih kaku. Pada fase ini ion natrium dan fluor tidak berperan dalam ikatan silang sehingga ion natrium akan menggantikan hidrogen dari gugus karboksil dan sisanya akan berikatan dengan fluor membentuk $\mathrm{NaF}$. Kemudian ikatan silang yang terbentuk akan dihidrasi oleh air sehingga bagian yang tidak bereaksi pada partikel kaca akan diselubungi oleh gel silika yang terbentuk selama pelepasan kation dari permukaan partikel. Pada akhirnya, semen yang mengeras akan membentuk gumpalan partikel yang tidak bereaksi dan dikelilingi oleh silika didalam matrik yang amorf dari kalsium hidrat dan campuran garam alumunium. ${ }^{13,16}$

Saat terjadi pengerasan awal pada resin modified glass ionomer cement dan berkontak dengan air maka reaksi pengerasan akan dihambat sehingga merusak permukaan semen. Sensitifitas terhadap air dapat dikurangi dengan pencampuran fotopolimerisasi sehingga mempercepat proses pengerasan. Percepatan pengerasan akan menunjang estetik dari hibrid ionomer. Dengan kata lain, air tidak terlalu berpotensi untuk menghambat proses pengerasan setelah terjadi polimerisasi sempurna. ${ }^{13,16}$

\section{Sifat Resin Modified Glass lonomer}

Sifat yang dimiliki resin modified glass ionomer cement hampir sama dengan sifat generasi awalnya (SIK). Penambahan HEMA mampu memperbaiki kekurangan dari SIK terutama dari sifat mekanik dan 
estetik. $^{2}$ Penambahan HEMA diduga dapat membahayakan jika diletakkan langsung di sel pulpa. Hal ini sesuai dengan penelitian Nicholson dkk yang menyatakan bahwa kandungan HEMA dapat menyebabkan toksisitas di daerah sel pulpa akibat mampu mengurangi intraselular glutation level serta mampu menyebabkan reraksi alergi. ${ }^{17}$ Penelitian Kanjevac menyatakan material dengan unsur fluor yang tinggi dapat menyebabkan kematian Dental Pulp Steam Cell (DPSC). ${ }^{18}$ Namun unsur fluor dipercaya dapat membantu peningkatan kekerasan permukaan email/ dentin gigi. ${ }^{19}$

Kekerasan permukaan material ini sedikit lebih rendah dibandingkan dengan bahan restorasi lain (resin komposit dan kompomer). Hal ini disebabkan sifat dari hibrid ionomer yang lebih mendekati sifat glass ionomer cement. ${ }^{20}$ Nilai fleksural strength adalah $71,1-82.1 \mathrm{MPa}$, diametral tensile strength adalah 37.9-47.5 MPa. Nilai fleksural strength dan diametral tensile strength ini lebih tinggi dari semen ionomer kaca konvensional oleh karena adanya ikatan yang kuat antara partikel kaca dengan matrik polimer. ${ }^{21}$ Kekuatan kompresi dari resin modified glass ionomer cement adalah 243.5 - 306.2 MPa. ${ }^{21}$

Resin modified glass ionomer bertahan dalam kondisi rongga mulut lebih baik dibandingkan glass ionomer cement. Penelitian Hubel dkk menyatakan resin modified glass ionomer cement mampu bertahan selama 3 tahun setelah ditumpat dengan Vitremer (RMGIC) dibandingkan SIK. ${ }^{22}$ Observasi yang dilakukan oleh Das dkk, resin modified yang diaplikasikan pada anak usian3,5- 5,5 tahun dapat bertahan selama lebih dari 1 tahun dan dapat digunakan sebagai restorasi klas III gigi sulung. ${ }^{23}$

Kemampuan resin modified glass ionomer ini untuk melepaskan ion fluor

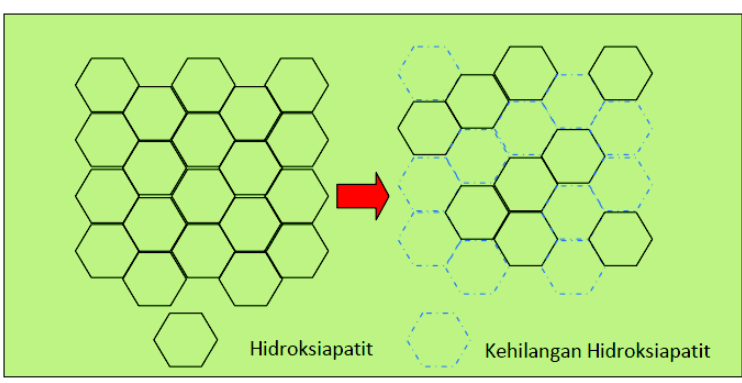

Gambar 2. Porus yang terbentuk pada email gigi

\section{DISKUSI}

Karies merupakan suatu proses demineralisasi yang terjadi secara terus menerus pada permukan gigi akibat proses fermentasi karbohidrat menjadi asam. ${ }^{24}$ Proses demineralisasi semakin meningkat pada anak disebabkan konsumsi makanan yang manis dan lengket yang merubah karbohidrat menjadi glukosa. ${ }^{12,24}$ Proses demineralisasi yang terus menereus dapat menyebabkan 
terlepasnya ion-ion yang terkandung di dalam gigi (hidroksiapatit) seperti ion kalsium (Ca) dan fosfat (PO4)2. Proses awal terjadi karies dapat diamati dari ilustrasi gambar 1. ${ }^{24}$

Ilustrasi Gambar 1 menunjukkan peluang untuk terjadinya karies anak semakin tinggi akibat ion $\mathrm{H}+$ (asam) yang terbentuk semakin meningkat. Ion $\mathrm{H}+$ yang terbentuk akan mendestruksikan hidroksiapatit terutama pada selubung prisma email sehingga mengurai senyawa tersebut menjadi ion $\mathrm{Ca} 2+$, PO43- dan $\mathrm{OH}-$. Proses ini terjadi terus menerus mencapai daerah interprismatik dan terus melarutkan ion-ion yang terdapat dibawah email gigi. Proses tarik menarik secara kimia ini menyebabkan terlepasnya ion-ion tersebut dan berikatan dengan ion asam dan membentuk porus pada permukaan email gigi. ${ }^{24}$ Perubahan keadaan prisma email dapat dilihat pada Gambar 2.

Kondisi kehilangan hidroksiapatit ini menimbulkan karies yang terus membesar jika tidak diatasi dengan tindakan

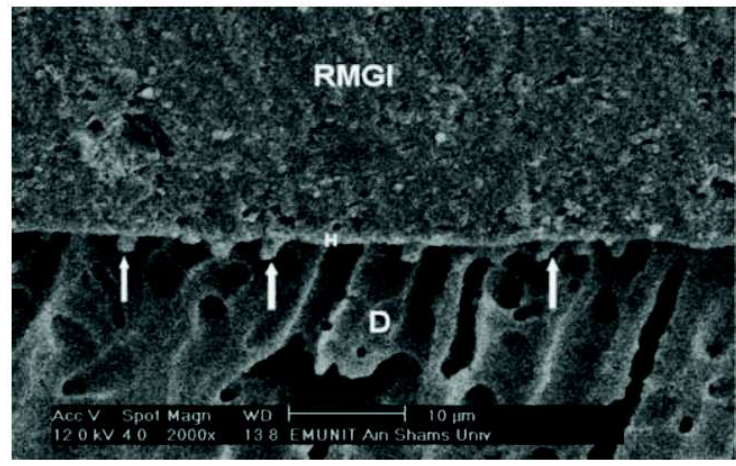

Gambar 3. Adhesi yang terjadi antara dentin dengan resin modified glass ionomer cement dengan penambahan kondisioner. ${ }^{26}$

rehabilitasi. Anak-anak dengan ukuran email gigi yang lebih tipis dibandingkan email gigi dewasa dapat mempercepat proses karies. Salah satu tindakan yang dapat menghentikan perkembangan karies yang sudah membesar adalah dengan menumpat/menambal dengan resin modified glass ionomer cement.
Penggunaan resin modified glass ionomer cement dari beberapa penelitian sering digunakan pada restorasi dengan beban oklusal yang rendah namun penelitian Croll menunjukkan hampir 93\% material ini dapat digunakan untuk restorasi klas I dan klas II gigi sulung yang diketahui memiliki beban kerja yang lebih besar

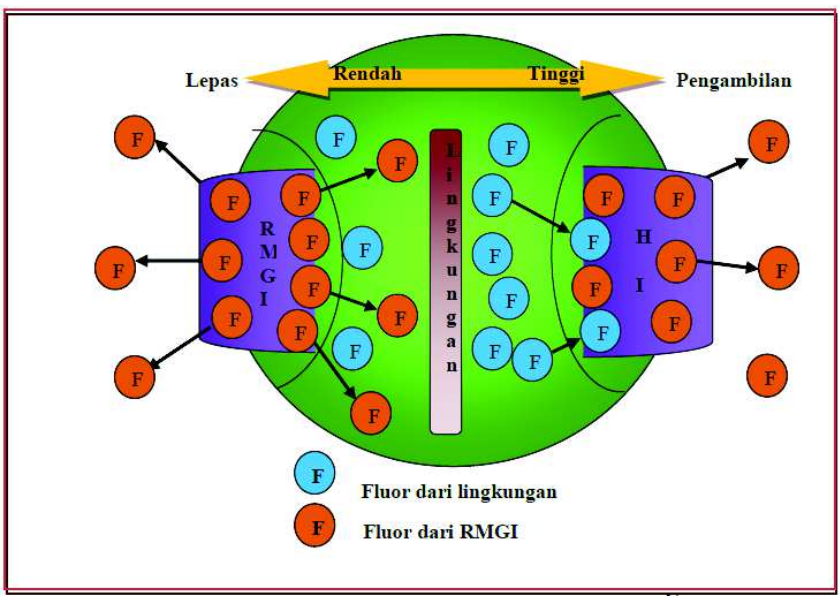

Gambar 4. Proses pertukaran ion RMGILingkungan/saliva/gigi. ${ }^{24}$

dibandingkan restorasi klas III, IV, dan V. ${ }^{25}$

Tingginya sifat mekanik dari resin modified glass ionomer cement ini juga dapat meningkatkan shelf life dari material ini. ${ }^{22,23} \mathrm{Hal}$ ini sangat dipengaruhi oleh adhesi material restorasi dengan gigi. (Gambar 3) Adhesi yang terjadi antara gigi dengan restorasi terjadi akibat adanya pertukaran ion seperti "generasi awalnya". Selain pertukaran ion, reaksi yang terjadi pada resin modified glass ionomer cement adalah reaksi polimerasi dimana terjadi ikatan hidrogen antara polimer HEMA dengan asam poliakrilat. Reaksi ini menghasilkan material restorasi menjadi kuat dan mengurangi kontaminasi air. ${ }^{2}$ Disamping itu material ini memiliki kelebihan yang tidak dimiliki oleh semen ionomer kaca konvensional yaitu: sifat estetis yang lebih baik, proses pengerasan yang berlangsung cepat dan juga lebih tahan terhadap beban kompresi. ${ }^{20,21,24}$ Adhesi yang terjadi pada reaksi polimerisasi dapat dilihat pada 


\section{Gambar 3.}

Gambaran diatas menunjukkan ikatan yang terjadi antara material dengan gigi dimana terlihat adanya resin tag yang pendek $(\mathrm{H}) .26 \mathrm{Hal}$ ini terjadi akibat asam poliakrilat membuang smear layer pada permukaan gigi tanpa membuka tubulus dentin terlalu besar. Jarak resin tag yang pendek diasumsikan cukup memadai untuk digunakan sebagai bahan tumpatan gigi sulung. Resin tag dapat menyebabkan peningkatan sifat mekanik dari material salah satunya shearbond. ${ }^{26}$ Shearbond sangat penting untuk melihat ikatan antara material dengan dentin. penelitian Suryakumari $\mathrm{N}$ menunjukkan kekuatan shearbond RMGIC - gigi sulung (9,7 MPa) lebih baik dibandingkan GICc gigi sulung $(3,81 \mathrm{MPa}){ }^{27}$

Resin modified glass ionomer cement berdasarkan penelitian Adel dkk menunjukkan resin modified glass ionomer cement dan giomer sangat potensial untuk meremineralisasi daerah yang terdemineralisasi atau disebut dengan affected dentin setelah mengevaluasi setelah 6 bulan dibandingkan resin komposit. ${ }^{19} \mathrm{Hal}$ ini disebabkan adanya pelepasan ion fluor dari material restorasi ke permukaan gigi (email/ dentin). Pelepasan yang terus menerus dapat menyebakan meningkatnya kekerasan permukaan pada daerah yang terdemineralisasi. ${ }^{15}$

Material ini memiliki waktu pengerasan yang lebih cepat dibandingkan glass ionomer cement. Pengerasan yang singkat dapat menyebabkan anak-anak cenderung lebih nyaman dan tidak bosan saat pengerjaan. Penambahan HEMA diketahui dapat mengurangi sensitivitas semen terhadap air sehingga semen lebih cepat mengeras. Kondisi remineralisasi terlihat jelas pada simulasi material restorasi pada rongga mulut. Adanya ionion yang terkandung dalam saliva dan gigi menyebabkan semen ini semakin kuat. Proses remineralisasi diperkirakan ion fluor yang terkandung di dalam larutan remineralisasi akan berdifusi ke dalam matriks resin sehingga kekerasan semen meningkat kembali. Ion fluor (F-) pada larutan perendaman dapat berikatan dengan ion kalsium ( $\mathrm{Ca} 2+)$ dari spesimen sehingga akan membentuk CaF2 yang mudah larut dan akan terdeposisi pada daerah porus sehingga dapat mempertahankan kekerasan permukaan hibrid ionomer. ${ }^{24}$

\section{KESIMPULAN}

Resin modified glass ionomer cement, berdasarkan sifatnya jauh lebih baik dibandingkan glass ionomer cement. Material ini mampu mempertahankan keunggulannya dalam mencegah karies (melepaskan ion fluor) sehingga dapat menghambat proses demineralisasi karies pada gigi sulung. Dengan shelf life yang cukup lama dan estetik, material ini dapat digunakan sebagai restorasi gigi sulung dengan beban kompresi yang tinggi ataupun tidak.

\section{DAFTAR PUSTAKA}

1. Albers HF. Tooth Colored restorative principles and teqniques. In, 9 ed. London: BC Decker Inc. 2002. 19-80.

2. Mount GJ, Hume WR. Preservation and restoration of tooth structure, 2 edn. Australia: knowledge Books and Software. 2005.

3. Mount.G.J. An atlas of glass ionomer cement: a clinician's guide In. New York: Martin Dunitz. 2002. 1-22.

4. Attar.N, MD T. fluoride release and uptake capacities of fluoride releasing restorative materials. J Op Dent 2003; 28: 395402.

5. Lobo.M.M, Pecharki.G.D, Tegan.C et al. Fluoride release capacity and cariostatic effect provided by sealent. J Oral Sci 2005; 47: 3541.

6. Nakajo.K, Takahashi.Y, Kiba.W et al. Fluoride ion released from glass ionomer cement is responsible to inhibit the acid production of caries related oral streptococci. J Interface Oral Health Sci 2007: 263-4.

7. Tyas.M.J. Clinical performance of glass ionomer cements J Minimal Interv Dent 2008; 1: 84-94.

8. Seixas IC, Seixas FH, Ciccone JC et al. Demineralization around restorations with different restorative materials containing fluoride. materials research 2004; 7: 235-40.

9. Carey CM, Spencer M, Gove RJ et al. Fluoride 
Release from a Resin modified Glass-ionomer Cement in a Continuous-flow System: Effect of pH. J Dent Res 2003; 82: 829-32.

10. Ngo HC, Mount G, Intyre JM, Tuisuva J, Von Doussa. Chemical exchange between glassionomer restorations and residual carious dentine in permanent molars:An in vivo study. journal of dentistry 34 (2006) 608-613

11. Mjor IA, Fejerskov O. Human oral embriology dan histology 1ed. Munksgaard, Copenhagen 1986:81

12. Sumarti. Hubungan antara konsumsi makanan kariogenik dan kebiasaan menggosok gigi dengan timbulnya penyakit karies gigi sulung pada anak prasekolah usia 4-6 tahun di Desa Sekaran Kecamatan Gunung Pati Semarang (2007).skripsi.universitas semarang

13. Silva RC, Zuanon ACC, Esberard RR et al. In vitro microhardness of glass ionomer cements. J Mater Sci: Mater Med 2007; 18: 139-42.

14. Kanchanavasita W, Anstice HM, Pearson GJ. Long-term surface micro-hardness of resinmodified glass ionomers. J Dent 1998; 26: 707-12.

15. David CL. Advances in glass ionomer cements. J Appl Oral Sci 2006; 14: 3-9.

16. Wang $X Y$, Yap AUJ, Ngo HC et al. Enviromental degradation of glass ionomer cements: a depth sensing microindentation study. J Biomed Mater Res 2006.

17. Nicholson JW, Czarnecka B. the biocompability of resin-modified glass-ionomer cement for dentistry. Dental Material 2008;24:1702-8

18. Kanjevac T, Milovanovic M, Volarevic V, Lukic $\mathrm{ML}$, Arsenijevic N, Marcovic D. Cytotoxic Effect of glass ionomer cement on human dental pulp steam cells correlate with fluoride realease. Mecanical Chem 2012:8:40-5

19. Khairy MAE, Elwakeel A. In vitro evaluation of remineralizing capacity of fluorine realeasing restorative materials at the internal cavity wall and external margin. Cairo Dental Journal 2007;23(2):239-47

20. Bayindir YZ, Yildiz M. Surface Hardness Properties of Resin-Modified Glass ionomer cements and Polyacid-Modified Composite Resins. The Journal of Contemporary Dental Practice 2004; 5: 1-6.

21. Xie D, Brantley WA, Culbertson BM et al. Mechanical properties and microstructure of glass ionomer cements. J Dent Mater 2000; 16: 129-38.

22. Hubel S, Mejare I. Conventional versus resin modified glass ionomer cement for Class II restoration in primery molar: A 3-year clinical study. int J paediatr Den.2003;13(1):2-8

23. Das UM, Viswanath $D$, Azher U. Clinical Evaluation of resn composite and resin modified glass ionomer in class iii restorations of primary maxillary incisors: a comparative in vivo study. Int $\mathrm{J}$ of Clinc Pediatric Dentistry 2009;2(2):13-9

24. Mount GJ, Hume WR. Preservation and restoration of tooth structure 2ed. Australia: knowladge Books and Software.2005:98-100

25. Croll TP, Bar-Zion Y, Segura A, Donly KJ. Clinical performance of resin-modified glass ionomer cemen restorations in primary teet: A retrospective evaluation. J Am Dent Assoc 2001;132(8):1110-6

26. El Askari FS, Nassif MS. The Effect of the PreConditioning Step on the Shear Bond Strength of Nano-Filled Resin-Modified Glass-lonomer to Dentin. Eur J Dent 2011;5:150-6

27. Nujella BPS, Choudary MT, Reddy SP, Kumar KM, Gopal T. Comparison of Shear Bond Strength of Aesthetic Restorative Materials. Contemporary Clinical Dentistry 3.1 (2012): 22-26. PMC. Web. 4 Jan. 2015.

28. Leme AFP, Tabchoury CPM, Zero DT et al. effect fluoridated dentifrice and acidulate phosphate fluoride application on early artificial carious lesions. J Am Dent 2003; 16: 91-5 